\title{
Composition of the Top Management Team and Firm International Diversification
}

\author{
Laszlo Tihanyi \\ University of Oklahoma \\ Alan E. Ellstrand \\ University of Arkansas \\ Catherine M. Daily \\ Dan R. Dalton \\ Indiana University
}

\begin{abstract}
This study investigates the impact of various top management team characteristics on firm international diversification. Relying on data from 126 firms in the electronics industry, we find that certain top management team characteristics are related to international expansion. Specifically, results indicate that lower average age, higher average tenure, higher average elite education, higher average international experience, and higher tenure heterogeneity are associated with firm international diversification. The study reinforces the importance of top management team composition in internationalization decisions and suggests further research in this context. (C) 2000 Elsevier Science Inc. All rights reserved.
\end{abstract}

Establishing international markets is one of the most important challenges firms face, especially during the growth phase. The advantages of international expansion have been outlined in the internationalization literature (e.g., Hymer, 1976; McKiernan, 1992; Rugman, 1981; Vernon, 1966). Notably, however, recent empirical research suggests that there are potential threats associated with the internationalization process as well (Hitt, Hoskisson, \& Kim, 1997; Mitchell, Shaver, \& Yeung, 1992). Various aspects of international operations, such as entry mode, ownership mode, collaboration, competition, cultural differences, and organizational implications, have been studied extensively. Although many of these studies acknowledge the importance of corporate executives in the internationalization process, relatively little research has focused specifically on the role of top management teams in the decision to internationalize.

Direct all correspondence to: Laszlo Tihanyi, Division of Management, Michael F. Price College of Business, University of Oklahoma, 307 West Brooks, Norman, OK 73019-4006; e-mail: <ltihanyi@ou.edu>.

Copyright @ 2000 by Elsevier Science Inc. 0149-2063 
There is an increasing research effort in the management literature dedicated to better understanding the role of top management teams. A stream of research, largely originating from Hambrick and Mason's (1984) upper echelons perspective, has investigated the role of top management teams in important organizational decisions (e.g., Bantel \& Jackson, 1989; Finkelstein \& Hambrick, 1990; Hambrick, Cho, \& Chen, 1996; Murray, 1989). The research reported here extends this stream of research by focusing on the relationship between top management team characteristics and firm international diversification.

We focus on the electronics industry during its initial international expansion in the mid-1980s. During this period American corporations significantly increased their international business operations. For example, the value of foreign firms acquired by U.S. firms during the 1980s was ten times the level of foreign acquisitions during the 1970s. Markides and Ittner (1994) found that a significant portion of these firms had no prior international operations.

The majority of foreign acquisitions during the 1980s were noted in the manufacturing sector. Among U.S. manufacturing firms, the electronics industry, along with the food and pharmaceutical industries, reported the greatest amount of foreign acquisition activity during the period (Markides \& Ittner, 1994). International diversification provided new opportunities for electronics firms as they emerged from the turmoil that the industry endured during the recession of the early 1980s. From 1985 to 1987 , foreign sales as a percentage of total sales for leading firms in the electronics industry increased from $14 \%$ of sales to $24.7 \%$ of sales (Electronic Business, 1988), an expansion of 76.4\%. As an electronics industry analyst noted at that time "... companies that have recognized the importance of foreign markets. . . stand ready to prosper. ... [C]ompanies that have ignored overseas markets will pay the price" (Electronic Business, 1986: 87).

The purpose of this study is to extend previous work on the nature of the relationship between the composition of top management and firm international diversification. By examining the demographic traits of top management teams (e.g., age, tenure, education, elite education, international experience), as well as team heterogeneity, we hope to gain additional insights into the characteristics of top management teams that were proactive in leading their firms into international markets. We employ a multidimensional measure of international diversification as our dependent variable. To avoid potential confounds, we focus our study on a single industry during a period of rapid internationalization. The following sections include a review of prior research on international diversification and top management teams, conceptual linkages among top management team characteristics and the degree of international diversification, the research design and methodology on which we rely, the results of the research, and implications for future research.

\section{Background}

\section{International Diversification}

Corporate executives consider the diversification of business activities across national borders to be a complex strategic decision. The complexity associated with geographic diversification decisions may be due, in part, to the increased 
opportunities and threats that executives encounter in international markets. Whereas there is agreement in the literature that international diversification affects firms, empirical results have been mixed on the specific direction of these influences (Hitt et al., 1997; Tallman \& Li, 1996).

An extensive body of research suggests that international diversification provides firms significant benefits. Advantages associated with internationalization are illustrated by studies on foreign direct investment (Dunning, 1988; Hymer, 1976), international product life cycle models (McKiernan, 1992; Vernon, 1966), oligopolistic competition (Caves, 1996; Kindleberger, 1969), and the operations of multinational firms (Grant, 1987; Hennart, 1982; Rugman, 1981). Empirical findings indicate that international diversification produces higher firm performance than domestic product diversification (Hitt, Hoskisson, \& Ireland, 1994; Kim, Hwang, \& Burgers, 1993). Additionally, Hughes, Longue and Sweeney (1975) found that multinational corporations provided higher returns than did domestic firms. Studies have also documented higher risk-adjusted returns for multinational, as compared to domestic, firms (Lessard, 1973; Rugman, 1976).

International diversification, however, is not without risk. International exposure increases the level of uncertainty business face in their domestic markets. Misunderstanding factors such as consumer tastes, regulations, retaliation from local and multinational players, or access to distribution, may result in damaging and costly mistakes (Mitchell et al., 1992). Increased international diversification may also lead to organizational problems. Due to increased size and complexity, multinational companies may have higher monitoring costs than domestic firms (Fatemi, 1984; Geringer, Beamish, \& daCosta, 1989).

Studies have also demonstrated that there are performance declines associated with increased international diversification. Michel and Shaked (1986), for example, found performance to be higher for domestic firms than for multinational firms. A study by Collins (1990) reported that multinational firms with developing country operations had lower performance than domestic firms and multinationals with developed country operations. However, this study did not find performance differences between the latter two groups.

Geringer et al. (1989) suggest that the relationship between international diversification and firm performance may be curvilinear. These researchers proposed that higher levels of international diversification were associated with performance declines. Consistent with the propositions of Geringer et al. (1989), Hitt et al. (1997) noted that the eventual performance decline might be due to the increased complexity of international operations.

Although there are conflicting research findings, there seems to be an agreement in the literature that international diversification decisions may influence firm performance. As a result, international diversification may be of interest to corporate executives. Research examining the decision-making processes within multinational companies has contributed significantly to our understanding of internationalization decisions. Building on findings in other areas of management (e.g., Bower, 1970; Tushman \& Romanelli, 1985), the "process school of internationalization" focused on the decision making of top management teams in 
international markets (Bartlett \& Ghoshal, 1987; Doz \& Prahalad, 1984; Hamel \& Prahalad, 1989; Malnight, 1995; Prahalad \& Bettis, 1986).

To better understand how executives deal with uncertainties in international markets, some recent studies have focused on the characteristics of top management teams (Athanassiou \& Nigh, 1999; Sambharya, 1996; Wiersema \& Bird, 1993). Although these studies examined top management teams in different roles, they seem to agree that, through their decisions, the characteristics of these decision-making bodies may have an effect on organizational success. The present study aims to extend our understanding of the factors that influence international diversification by focusing on the role of the top management team in expanding international operations. Specifically, we examine the composition of the top management team to consider whether particular demographic characteristics are associated with international diversification.

\section{Top Management Teams}

In recent years, management researchers have placed an increased emphasis on investigating the influence of management on corporate performance (Thomas, 1988). An important focus of this research has been to examine the linkages between the characteristics of top organizational managers and a variety of organizational outcomes (Bantel, 1993; Michel \& Hambrick, 1992; Wiersema \& Bantel, 1992). This trend has emerged as a result of two important theoretical developments in organizational studies. The first development was the concept of the dominant coalition, suggested by Cyert and March (1963), which shifted the level of analysis employed in studies of organizational leadership from the individual (CEO) to the entire team of top managers. The second development is the increased emphasis on employing observable demographic characteristics (e.g., age, tenure, experience) in organizational research and exploring the relationship between these characteristics and organizational outcomes (e.g., Pfeffer, 1983).

The dominant coalition concept and demographic research were united in the seminal work of Hambrick and Mason (1984). They proposed that specific organizational outcomes are associated with top management teams possessing particular demographic profiles. At the heart of this upper echelons perspective is the belief that the background, experiences and values of corporate executives influence important strategic decisions enacted by these key corporate actors. They also suggested that observable characteristics such as age, tenure and functional experience might serve as useful proxies for the cognitive base that guides top executive decisions.

This demographic approach, however, has recently been criticized (cf., Aldrich, 1979; Lawrence, 1997; Pettigrew, 1992). The central concern is the need to access the "black box" that may provide the operative mechanism linking demographic factors and organizational outcomes (e.g., Finkelstein \& Hambrick, 1996). Pettigrew, for example, suggested that little is known about "the processes by which top teams go about their tasks" (1992: 178). Lawrence (1997) noted that demographic variables are often used as proxies for subjective concepts. She observed that researchers relying on the demographic approach apply a congru- 
ence assumption in which demographic variables are used to represent subjective concepts without providing a rationale for why this is a valid approach.

Recent research exploring team demography and processes has, in fact, provided valuable insights into the reported "black box." Smith et al. (1994), for example, found that top management team demography was indirectly related to performance through intervening process variables including social integration and communication. Pelled, Eisenhardt, and Xin (1999) found that team demographic diversity influenced conflict, which in turn, influenced group performance. These researchers also found that these relationships were further moderated by task routineness and group longevity. In a computer simulation study, Carroll and Harrison (1998) found that tenure heterogeneity in an organization or team was positively related to the organization's cultural heterogeneity. They also noted that various social processes underlie this relationship.

Although there are limitations inherent in any approach, we would note that there is a stream of research relying exclusively or primarily on top management team demographic variables that has yielded significant findings. These studies have largely focused on two dimensions of team composition. The first set of studies is focused on the influence of demographic traits on organizational outcomes and is based on the belief that specific demographic characteristics are associated with executive perceptions that ultimately lead to certain actions and outcomes. Several of these studies identified significant relationships between top management team demographic characteristics and corporate strategies (Bantel, 1993; Bantel \& Jackson, 1989; Finkelstein \& Hambrick, 1990; Wiersema \& Bantel, 1992). Other researchers found associations between top management team demographic characteristics and corporate performance (Finkelstein \& Hambrick, 1990; Haleblian \& Finkelstein, 1993; Smith, Smith, Olian, Sims, O’Bannon, \& Scully, 1994).

A second stream of research in this area examined the effects of top management team heterogeneity. Studies have identified significant relationships between various measures of heterogeneity and corporate strategic outcomes (Bantel, 1993; Bantel \& Jackson, 1989; Hambrick et al., 1996; Lant, Milliken, \& Batra, 1992; Wiersema \& Bantel, 1992). In addition, researchers have established an association between top management team heterogeneity and corporate performance (Hambrick et al., 1996; Keck, 1997; Murray, 1989).

Extensions of the upper echelon perspective into the international context have been limited. Wiersema and Bird (1993) examined the influence of the demographic characteristics of top managers in 40 large Japanese firms on top management team turnover. Their findings indicated that Japanese firms with more heterogeneous top management teams (based on age, team tenure and educational prestige) had higher levels of management turnover. These results were stronger than results for similar U.S. firms. Sambharya (1996) examined the influence of executives' international experience on international involvement in large multinational corporations and found that top management teams with a higher mean foreign experience and greater heterogeneity of foreign experience were associated with the firm's international involvement. In a recent study, Athanassiou and Nigh (1999) found that the extent of a firm's internationalization 
was related to the top management team's international business advice network density.

In light of these findings, there seems to be continued promise in reliance on the demographic approach (e.g., Finkelstein \& Hambrick, 1996). As noted by Lawrence, demographic variables have desirable properties, "thus providing high content validity and replicability which is an important consideration in a field where replication is all too infrequent" (1997 :16). Furthermore, Pfeffer (1983) has suggested that the use of observable managerial characteristics may help to address the limitations associated with subjective research that often includes measurement error, differences in conceptualizations and low levels of explained variance. This sentiment is mirrored by Finkelstein and Hambrick (1996: 47) who noted, ". . . an executive's tenure in the firm is open to essentially no measurement error." Moreover, in response to the limitations of reliance on psychological, as compared to demographic, variables, Finkelstein and Hambrick (1996) observed that demographic variables are far more accessible to researchers, as top executives are typically unwilling to "submit to batteries of psychological tests" (p. 46).

The decision that firms makes to expand into international markets is a consequential judgment that requires careful review and consideration of a vast array of complex environmental factors. Extending the demographic approach into the study of firms' international business activity may lead to better understanding of the role of the top management team in international diversification. In the following section we develop specific hypotheses that examine the relationships between top management team demography and heterogeneity and firm international diversification.

\section{Hypothesis Development}

This study includes examination of five demographic variables: age, education, functional background, international experience, and tenure on the top management team. We examined the influence of demographic traits as well as team heterogeneity, as both have been shown to relate to specific corporate outcomes (Bantel, 1993). Previous research suggests that these selected demographic measures may be valid proxies for attitudes about international diversification decisions.

\section{Demographic Traits}

Average age. Prior research has demonstrated that younger managers are associated with greater strategic change (Wiersema \& Bantel, 1992). Based on these findings, older executives may be less willing to adapt to new ideas or behaviors (Bantel \& Jackson, 1989). In addition, older executives may be at a stage in their careers where financial security is important and risk-taking behaviors may be seen as a threat to that security (Wiersema \& Bantel, 1992). Finally, older managers may have a greater stake in supporting the status quo, as it reflects the strategies they adopted over the years (Hambrick \& Mason, 1984).

The complexity and risk associated with international expansion may represent a formidable challenge to top executives. Such a strategic initiative may be 
more attractive to younger, energetic managers willing to accept the risk associated with global expansion in exchange for the potential reward of career advancement. As Hambrick and Mason note, younger managers may be more oriented toward "attempting the novel, the unprecedented, taking risks" (1984: 198). Therefore:

H1: Higher average age of the top management team will be negatively related to the degree of the firm's international diversification.

Average top management team tenure. Tenure within a group is an important determinant of group process. Increased tenure is associated with stability, reduced conflict and superior communication (Katz, 1982). In addition, Michel and Hambrick (1992) suggest that longer tenure on the top management team may be associated with social cohesion and shared cognitive structures. These team attributes may enhance socialization and lead to better firm performance (Carroll \& Harrison, 1998, Smith et al. 1994). Other researchers, however, argue that executive team tenure may also be associated with negative effects (Keck, 1997). Executives who serve together for extended periods of time may tend to develop similar views since the long-term acculturation of team members may lead to a common perspective or corporate paradigm (Pfeffer, 1983). This can result in dysfunctional decision processes including "groupthink," a collective pattern of defensive avoidance (Janis \& Mann, 1977; Keck, 1997).

Still, due to the complex and uncertain nature of international diversification decisions, a shared understanding of the international environment may be critical. Executives with longer tenure on the top management team may develop more accurate shared cognitive structures about new environments. Additionally, longer tenure may provide the opportunity for team members to better assess firm capabilities suitable for international diversification. Therefore:

H2: Higher average tenure of the top management team will be positively related to the degree of the firm's international diversification.

Elite education. Education provides another important dimension that helps shape an individual's cognitive base (Hambrick \& Mason, 1984). Recent research has suggested a unique influence associated with an elite education. Finkelstein, in his study of power in top management teams, stated that "attendance at certain schools carries with it an aura of prominence" (1992: 516), and suggests that managers with elite educational credentials may enjoy enhanced prestige. Central to this research is the concept that elite educational institutions provide their students with more than just a formal education. As Domhoff notes, "elite educational institutions are instrumental in transmitting the mentality and lifestyle that exists within the upper class" (1983: 24). Students attending such institutions are exposed to specific vocabulary, styles of dress, esthetic tastes, beliefs and values. The values associated with such a program may encourage students to have a more open-minded attitude toward other cultures (Domhoff, 1983). Elite institutions may also provide students with unique international 
educational experiences and the opportunity to meet other elites from diverse international backgrounds. Thus, executives with an elite educational background may be more aware of international issues and may be more inclined to view international opportunities favorably. Therefore,

H3: $\quad$ There will be a positive association between the average level of elite education on the top management team and the degree of the firm's international diversification.

International experience. Perlmutter (1969) suggested that international firms evolve through stages as they increase their international presence. In the early stages of international expansion, firms hold an ethnocentric orientation in which they possess the belief that home country practices should be used in all international operations. As firms increase their international experience, they gain a geocentric perspective, an approach that seeks to integrate diverse areas of the world through a global decision making process. Geocentrism has been associated with expansion into international markets as well as success in export operations (Dichtl, Koeglmayr, \& Mueller, 1990; Kobrin, 1994). Perlmutter (1969) noted that international assignments provide an important foundation for building a geocentric corporate orientation. More recently, Sambharya (1996) found that international experience among top executives might be an important determinant of international involvement.

International assignments may be associated with a higher degree of international diversification for several reasons. First, international assignments provide executives with a first-hand awareness of opportunities in overseas markets. In addition, international experience helps executives to reduce the anxiety and complexity associated with operating under conditions of greater uncertainty (Sambharya, 1996). Finally, while on international assignments, managers may make contacts that will be useful in facilitating future international ventures. Thus, international experience may be vital to a firm's international expansion. Therefore:

H4: There will be a positive association between the average level of international experience on the top management team and the degree of the firm's international diversification.

Team heterogeneity. Age heterogeneity may play an important role in influencing strategic decision-making. Different age cohorts experience different environmental events that have an important influence on shaping executives' attitudes and beliefs (Bantel \& Jackson, 1989). Noting that managers may have an influence on top management team demography through recruitment, Lawrence (1997) suggested that executives' perceptions of their own age in relation to others might influence decision-making processes. Age diversity should encourage the exchange of a wide variety of viewpoints that can lead to greater acceptance of change. This diversity of opinion might be particularly useful in the international arena where the environment is especially complex. 
The rationale concerning the heterogeneity of age cohorts may also apply to diversity of tenure on the top management team. Although teams that feature tenure homogeneity may reflect lower levels of conflict and better communication patterns, these teams might also lack the healthy diversity of perspectives that can stimulate more insightful discussion of international options (Bantel \& Jackson, 1989; Priem, 1990). Top management teams composed of executives who have widely differing amounts of team tenure may possess a wealth of diverse beliefs based on both societal as well as organizational experiences (Smith et al., 1994).

Prior research suggests that educational background influences strategic decision making processes and outcomes (Hitt \& Tyler, 1991). In our study, we focus on the diversity of educational specialization to consider the influence of education. Curriculum choices have been found to be associated with individual personalities, attitudes and cognitive styles (Wiersema \& Bantel, 1992). In considering a complex issue such as international diversification, a top management team with executives representing a broad and diverse educational base may be better equipped to deal with the wide range of relevant issues that must be considered.

In addition to educational background, work experience in functional areas has an important influence in shaping an executive's cognitive base (Bantel \& Jackson, 1989). As Hambrick and Mason stated “. . . functional-track orientation may not dominate the strategic choices an executive makes, but it can be expected to exert some influence" (1984: 199). Functional background has been found to significantly influence executives' analytical and decision making perspectives (Wiersema \& Bantel, 1992). Top management teams with a broader functional background will be better able to deal with environmental complexities (Finkelstein, 1992).

Top management teams with greater diversity of age, tenure, education or functional background may possess a more diverse set of values, experiences and beliefs. A broad base of experience can be effective in reducing some of the uncertainty associated with international expansion. Team heterogeneity might lead to more creativity and enhanced adaptability on the part of strategic decisionmakers (Murray, 1989). Priem (1990) suggested that team heterogeneity also leads to lower levels of consensus. He notes that consensus may be associated with higher levels of performance in dynamic environments. Additionally, Harrison, Price, and Bell (1998) found that the influences of demographic characteristics of team heterogeneity are reduced by interpersonal interactions over time. Due to the breadth of issues relevant to international expansion, as well as the complexity of the problems encountered in expanding into international markets, top management teams with a diverse base may be better equipped to guide the firm into new foreign markets. Therefore,

H5a: There will be a positive association between heterogeneity among the top management team with respect to age and the degree of the firm's international diversification.

\section{H5b: There will be a positive association between heterogeneity}


among the top management team with respect to tenure and the degree of the firm's international diversification.

H5c: There will be a positive association between heterogeneity among the top management team with respect to educational specialization and the degree of the firm's international diversification.

H5d: There will be a positive association between heterogeneity among members of the top management team with respect to functional background and the degree of the firm's international diversification.

\section{Methods}

\section{Sample}

Our sample is composed of firms in the U.S. electronics industry (SIC codes $3573,3574,3579,3674,3678$, and 3679). The selection of one industry was important to control for potential confounds such as the nature of products or markets on our dependent variable, international diversification. Additionally, as Child and Ellis (1973) note, different industries are characterized by different organizational environments that may exert an influence upon the role of corporate executives. We avoid these potential confounds by focusing on a single industry. In addition, although most prior studies have examined international diversification in cross-sectional settings, Tallman and Li (1996) suggest that effects across industries may influence international investment decisions. A rationale for our reliance on the electronics industry is that during the mid-1980s the industry was undergoing a period of rapid technological change characterized by volatile growth and instability (Geletakanycz \& Hambrick, 1997). Thus, the electronics industry at that time may have provided an environment that required greater managerial discretion (Eisenhardt \& Bourgeois, 1988; Virany, Tushman, \& Romanelli, 1992). More importantly for our study purposes, however, the electronics industry was entering a period of significant international growth in the mid-1980s (Electronic Business, 1986-1988; Markides \& Ittner, 1994). Thus, we were able to study an industry in the nascent stages of internationalization.

Firms included in our sample were selected from a comprehensive industry listing, Electronic Business 200. This publication is the annual survey of the largest U.S.-based computer and electronics manufacturers, ranked by sales. The survey is published by Electronic Business, a trade publication, and is a joint effort between the magazine and Arthur D. Little, Inc., a business consulting firm. Data on international diversification in the industry were first included in the survey in 1986. In an attempt to secure a sample with greater variability, we selected the period 1986 through 1988. Of the 200 largest firms listed on the survey, we excluded those that did not report separate data for international operations (59 firms). Demographic data were unavailable for 15 firms, resulting in a final sample of 126 firms. 


\section{Dependent Measure}

International diversification. Researchers have employed a variety of measures to examine international diversification. Perhaps the most frequently used measure of international diversification is foreign sales divided by total sales (FSTS) (e.g., Collins, 1990; Daniels \& Bracker, 1989; Grant, 1987; Rugman, Lecraw, \& Booth, 1985; Tallman \& Li, 1996). Measures similar to the FSTS measure include foreign assets divided by total assets and the number of international employees as a percentage of total employees. International diversification has also been measured by using the entropy approach that relies primarily on regional sales (Hitt et al., 1997) or employee data (Kim, Hwang, \& Burgers, 1989; 1993). Hitt et al. (1997) found a high correlation between the entropy method and FSTS measures. Another group of studies (e.g., Ramaswamy, 1993; Tallman \& Li, 1996) measured international diversification by using a country scope measure or the number of foreign countries with subsidiary operations.

Recent research has suggested that studies of international diversification rely on multidimensional measures to improve validity (e.g., Sullivan, 1994). Consistent with this, we measure international diversification as the average FSTS and the average country scope for the three-year period from 1986 to 1988 . We collected the FSTS data from the Electronic Business 200 annual survey. Country scope data were collected from the Directory of Corporate Affiliations: Who Owns Whom. A high correlation between FSTS and the country scope data indicated that the two variables might measure the same construct. The variables were combined using factor analysis.

\section{Independent Measures}

The top management team was defined as including the Chairperson of the Board, Vice-Chairperson, Chief Executive Officer, Chief Operating Officer, President, Senior Vice-Presidents, and Executive Vice-Presidents. Employing this method enables us to include the most important organizational decision-makers in our sample (Geletkanycz \& Hambrick, 1997; Murray, 1989; Sanders \& Carpenter, 1998). Information on executive characteristics was obtained for the year 1985 from the Dun and Bradstreet Reference Book of Corporate Managements, 1985. Top management team demographic data were coded using the following guidelines.

Age and tenure. Biographical data were examined to determine the age of all members of the top management team. Team tenure was computed based on the year each executive was promoted to the level of Vice President or higher.

Elite education. Data on elite education were collected by examining the executives' educational background and comparing the data with a list of elite universities used in previous studies (Finkelstein, 1992; Useem \& Karabel, 1986). Level of elite education for each executive was coded in the following manner: 0 in the case of no formal higher education; 1 when the higher education was completed at a nonelite university; 2 if any degree was obtained from an elite educational institution (graduate or undergraduate); and 3 when both undergraduate and graduate degrees were obtained from elite universities. 
International experience. Data on international experience were based on international education and work experience. Executive biographies were examined to identify international educational and work experience and each executive received a one or zero for each category. To assess the effects of multiple international experience and international education, these values were combined.

Educational background. Educational background was measured by identifying ten categories: undergraduate liberal arts, undergraduate science, undergraduate engineering, undergraduate business, undergraduate and graduate law, graduate science and art, graduate engineering, MBA, Ph.D., and other (e.g., executive programs). The educational experiences of executives were coded for each category-one if they hold a degree in that category, zero otherwise.

Functional background. Functional experience was divided into seven categories: general business, engineering, finance and accounting, marketing and public relations, research and development, production and operations, and legal. Executive biographical data were evaluated to determine the primary area of functional experience for each individual.

After the collection of individual level data, we aggregated the data in the following way. First, we calculated the average age and tenure of the top management teams. We calculated average elite education and international experience by aggregating the values for the members of a team and calculating the mean. The heterogeneity measures of age and team tenure were calculated by dividing the standard deviation by the mean, a measure for diversification of interval level variables (e.g., Murray, 1989). Educational heterogeneity and functional heterogeneity - both categorical variables - were based on Blau's (1977) heterogeneity measure: $\left(1-\Sigma\left(\mathrm{p}_{\mathrm{i}}\right)^{2}\right.$, where $i$ is the proportion of the team in the $i$ th educational or functional category).

\section{Control Variables}

Prior performance. Poor organizational performance may be associated with changes in corporate strategy (Tushman \& Romanelli, 1985). Firms that are performing poorly, for example, may seek new strategies to improve corporate performance (Hambrick \& Schechter, 1983). Thus, firms may seek to enter international markets to improve performance. By contrast, firms that lack an adequate resource base may be constrained in the strategic initiatives that they undertake (Barney, 1991). Thus, poor performance may limit a firm's ability to enter international markets. In any case, firm performance may influence a firm's ability to enter international markets; therefore, we include prior organizational performance as a control variable. Prior organizational performance was measured as the average return on assets (ROA) over the period of 1983 through 1985. ROA data were collected from Standard and Poor's COMPUSTAT database.

Size. A firm's size may also influence its ability to undertake strategic initiatives. Larger firms may possess the personnel and resources to facilitate entry into international markets. Larger firms, however, might also be more resistant to fundamental strategic change (Tushman \& Romanelli, 1985). To avoid any potential influence of firm size, we included this variable as a control in our 
analysis. We measured organizational size by using the number of organizational employees in 1985.

Top management team size. The size of the top management team may influence the level of heterogeneity found on the team. Large groups, for example, may contain members with more diverse backgrounds. Also, in a small group, measures are more volatile as the addition of one dissimilar member will change the group's composition significantly. Therefore, to limit possible effects related to the size of the top management team, we included this variable in our model. Top management team size was measured by the number of individuals on each firm's top management team.

\section{Results}

Table 1 presents the means, standard deviations, and correlations among the study variables. The hypotheses were tested using hierarchical multiple regression analysis. To evaluate the predictive power of the independent variables over the control variables, we used a two-step hierarchical regression analysis with all control variables entered in the first step. Before running these analyses, we examined the variables for possible problems related to their distribution and the assumptions of hierarchical regression analysis (Tabachnik \& Fidell, 1996). Because we found a significant level of skewness we used a logarithmic transformation for firm size and top management team size, a common transformation of these variables (Boeker, 1997; Westphal \& Zajac, 1997). The remaining variables were normally distributed with an acceptable range of skewness; therefore, no additional transformations were required. We tested our data for potential outliers by using both Mahalanobis' distance and Cook's distance measures; no outliers were found.

Table 2 presents the results of the hierarchical regression analysis. To examine the contribution of control variables (prior performance, firm size, and top management team size) these variables were entered as a single block in the first step. The first step of the hierarchical regression analysis illustrates that the control variables have no significant relationship with the degree of international diversification.

The independent variables, (i.e., average age, average team tenure, average elite education, average international experience, age heterogeneity, tenure heterogeneity, educational heterogeneity, and functional heterogeneity) were entered as one block in the second step. The addition of the top management team variables to the equation with the control variables resulted in a significant improvement in $R^{2}$ at $p<.001\left(F_{\text {inc }}=4.03\right)$. These results indicate that the composition of the top management team adds to the prediction of the degree of internationalization beyond the control variables. The significance of the standardized coefficients in the final model indicates that the demographic traits average age, average top management team tenure, average elite education and average international experience, are all significantly related to the degree of international diversification. Thus, hypotheses 1, 2, 3, and 4 are supported. Additionally, we found marginally significant results for the relationship between 


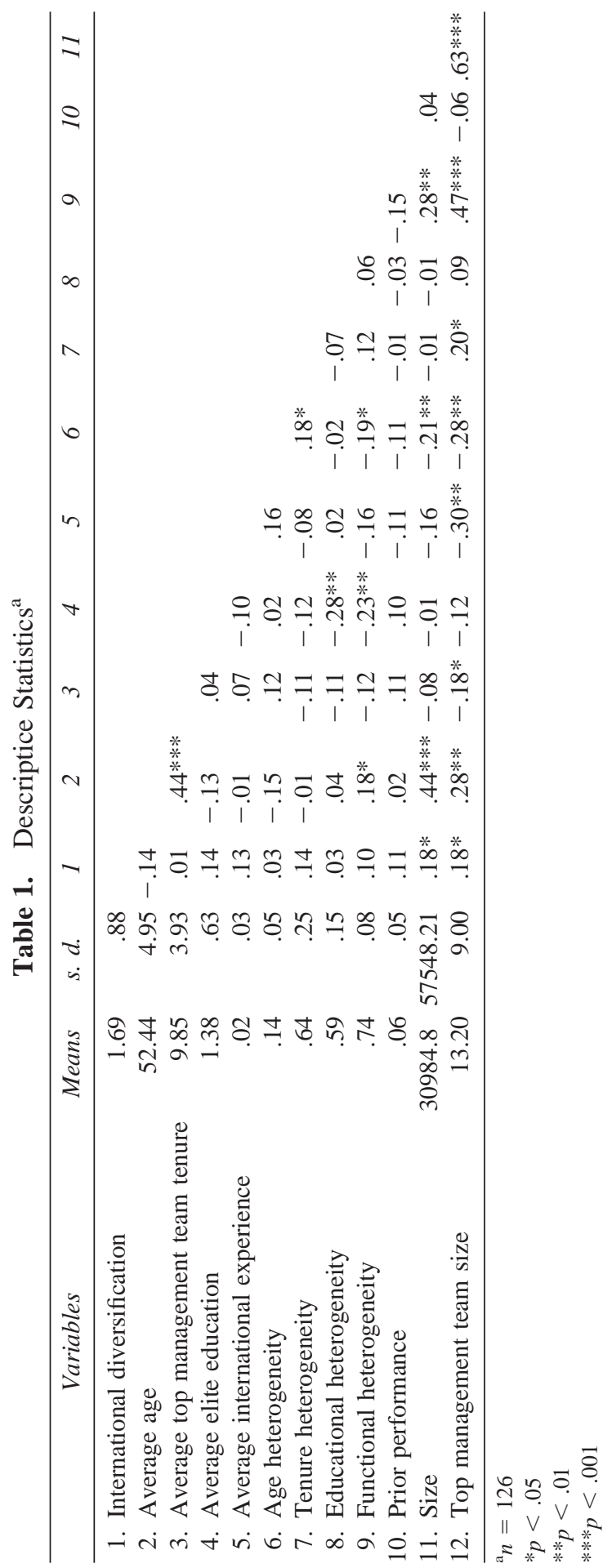


Table 2. Results of Hierarchical Regression Analysis

\begin{tabular}{lcc}
\hline \multicolumn{1}{c}{ Variables } & Step 1 & Step 2 \\
\hline Control variables & & \\
Prior performance & .12 & \\
Size & .09 & \\
Top management team size & .13 & \\
\hline Independent variables & & $-.43^{* * *}$ \\
Average age & & $.26^{*}$ \\
Average top management team tenure & & $.20^{*}$ \\
Average elite education & & $.27^{* *}$ \\
Average international experience & & .01 \\
Age heterogeneity & & $.17 \dagger$ \\
Tenure heterogeneity & .05 & .12 \\
Educational heterogeneity & & .12 \\
Functional heterogeneity & & $.26^{* *}$ \\
\hline $\mathrm{R}^{2}$ & $.21^{* * *}$ \\
$\Delta \mathrm{R}^{2}$ &
\end{tabular}

Standardized coefficients: $n=126$

$\dagger p<.10$

$* p<.05$

$* * p<.01$

$* * * p<.001$

top management team heterogeneity and international diversification, providing modest support for hypothesis 5b. The model indicates no significant effect for age heterogeneity, educational heterogeneity or functional heterogeneity. Thus, hypotheses $5 \mathrm{a}, 5 \mathrm{c}$, and $5 \mathrm{~d}$ are not supported. The variables in the final model explain $26 \%$ of the variance in international diversification.

\section{Discussion}

Our study extends previous research on international diversification by examining the relationship between the composition of the top management team and the firm's international diversification. We found that teams with younger managers, greater tenure on the top management team, members with elite educational backgrounds or members with international experience were associated with greater levels of firm international diversification. Thus, we support the contention that certain demographic characteristics of the top management team are associated with internationalization. Our results did not provide support for the hypothesized relationships between top management team heterogeneity and firm international diversification with the exception of a positive, marginal relationship between top management team heterogeneity and international diversification $(p<.10)$.

This study offers the following contributions to the management literature. Our findings provide additional evidence that top management teams influence the strategic direction of their firms through strategic decisions (Child, 1972; Cyert \& 
March, 1963). Prior research suggests that the decision to expand into international markets represents a critical strategic decision that requires careful executive consideration. Hickson, Butler, Cray, Mallory, and Wilson (1986) suggested that strategic decisions possess three specific characteristics that elevate the importance of these decisions. These theorists indicate that strategic decisions are rare, consequential and directive. Because of the complexity associated with analyzing international markets, as well as the consequences of the outcomes associated with these decisions, the decision to expand international operations constitutes an important strategic decision. Our findings indicate that the composition of the top management team may have a significant influence on the international diversification decision, once again supporting the contention that the top management team has an important influence on strategic outcomes.

This study offers additional support to the upper echelons perspective and extends demographic research further into the international domain. The relatively few findings in this area indicate that international experience among members of the top management team is associated with international diversification in multinational companies (Sambharya, 1996). Although our results confirm the association between the international experience of executives and internationalization, our results extend these earlier findings. The present study suggests that international expansion is associated with additional top management team demographic characteristics. Additionally, we studied the electronics industry at a time when many firms were changing their focus from the domestic market to international opportunities. Therefore, compared to previous studies that have focused on established multinational firms, this study provided an opportunity to examine the effects of the top management team during an industry's initial entry into international markets.

The results of this study extend our understanding about the influence of specific demographic traits on the decision to expand into international markets. We found that top management teams with younger executives may be associated with higher levels of international activity. This finding is consistent with the outcome of a previous study by Wiersema and Bantel (1992) in a domestic context. They found that younger top management teams were more likely to affect strategic change in their firms. Our results also confirm Hambrick and Mason's (1984) prediction that younger executives would be more likely to make risky, but potentially rewarding, decisions.

We found that top management teams with longer tenure were associated with higher levels of firm international diversification. This may indicate that longer tenured teams possess the levels of communication and shared cognitive properties necessary to accurately evaluate firm capabilities when entering international markets. This finding is consistent with most empirical studies on top management team tenure (Katz, 1982; Michel \& Hambrick, 1992; Smith et al., 1994). However, alternative outcomes (e.g., Keck, 1997) may indicate that additional research should be conducted in this area.

Our results also indicate that top management teams with a higher average level of elite education are associated with higher levels of international involvement. This outcome might suggest that elite educational experience provides 
executives with a broader world-view than other executives receive (Domhoff, 1983). Elite educational institutions in the United States have worldwide reputations for excellence and attract students from around the world. As a result, an elite educational experience may provide significant opportunities to interact with students from other countries. This experience may facilitate the appreciation of other cultures, reducing some of the uncertainty associated with international business ventures. In addition, the curriculum at elite schools may provide a greater emphasis on international issues. Thus, graduates from elite educational institutions may be more receptive to international opportunities and may be more inclined to pursue international expansion.

Finally, our results reveal that executives' international experience is associated with higher levels of firm international involvement. This finding is important as there is significant controversy over the value of international assignments and whether these assignments are beneficial to career development (Sambharya, 1996). Previous studies indicate that as many as $40 \%$ of international assignments are terminated prematurely because many expatriate employees fail to adapt to new environments (Black, 1988). Many executives hold the view that international assignments have an adverse effect on career development (Deresky, 1997). Our findings suggest that international assignments may provide executives with valuable experience that is useful in guiding their firms into new international markets. Black, Gregerson and Mendenhall (1992), suggested that international assignments are one of the most important factors in a firm's global competitiveness.

Our results offer limited support for the importance of tenure heterogeneity among members of the top management team. This finding is consistent with previous research that indicates that higher levels of team tenure diversity are associated with more insightful discussion of strategic options including international diversification (Bantel \& Jackson, 1989; Smith et al., 1994). We did not, however, find a significant association between top management team diversity with respect to age, education or functional background and international diversification of the firm. The lack of an association may be an artifact of the industry selected. The electronics industry in the 1980s was at a relatively early stage of development. Thus, a high technology, dynamic environment would be likely to attract executives of the same age with similar functional and educational backgrounds. Additional research should be conducted in other industry settings to better examine the generalizability of the relationship between these heterogeneity variables and firm international diversification.

Although we found strong associations between a number of the top management team demographic characteristics and international diversification, any attribution of causality would have to be interpreted with caution. As Markides and Ittner (1994) suggest, the electronics industry experienced its initial international expansion during the middle 1980s when firms had little prior international experience. As a result, it is possible that as firms increased their international activities, their top management teams took on the demographic characteristics that we identified. Future research should carefully consider not only the direction of causality, but also the possibility of reciprocal relationships. 
Although the present study suggests that the composition of the top management team may be an important determinant of international involvement, researchers should extend this research in several directions. In the present study, we developed a measure of international diversification based on foreign sales as a percentage of total sales and country scope. We urge researchers in this area to continue to refine measures of international activity. Researchers may also wish to perform a more fine-grained analysis of the influence of top management in international operations. This research could focus on more specific characteristics of executives such as country of origin and specific international assignments to determine how these experiences influence executive decision-making. Finally, researchers should prepare inductive studies of internationalization decisions to better understand how executive characteristics influence corporate decisionmaking.

In the current business environment, expansion into international markets is no longer a competitive advantage for most firms-it is an economic necessity. Firms must be able to take advantage of international opportunities to successfully survive in a complex, global environment. The findings of this study suggest that the composition of the top management team may play an important role in the international diversification of corporate operations.

\section{References}

Aldrich, H. E. 1979. Organizations and environments. Englewood Cliffs, NJ: Prentice-Hall

Athanassiou, N., \& Nigh, D. 1999. The impact of U.S. company internationalization on top management team advice networks: A tacit knowledge perspective. Strategic Management Journal, 20: 83-92.

Bantel, K. A. 1993. Top team, environment, and performance effects on strategic planning formality. Group and Organization Management, 18: 436-458.

Bantel, K. A., \& Jackson, S. E. 1989. Top management and innovation in banking: Does the composition of the top team make a difference? Strategic Management Journal, 10: 107-124.

Barney, J. 1991. Firm resources and sustained competitive advantage. Journal of Management, 17: 99-120.

Bartlett, C., \& Ghoshal, S. 1987. Managing across borders. The transnational solution. Boston, MA: Harvard Business School Press.

Black. J. S. 1988. Work role transitions: A study of American expatriate managers in Japan. Journal of International Business Studies, 19: 277-294.

Black, J. S., Gregerson, H. B., \& Mendenhall, M. E. 1992. Global assignments: Successfully expatriating and repatriating international managers. San Francisco, CA: Jossey-Bass Publishers.

Blau, P. M. 1977. Inequality and heterogeneity. Glencoe, IL: Free Press.

Boeker, W. 1997. Strategic change: The influence of managerial characteristics on organizational growth. Academy of Management Journal, 40: 152-170.

Bower, J. L. 1970. Managing the resource allocation process: A study of corporate planning and investment. Boston, MA: Harvard University Press.

Carroll, G. R., \& Harrison, J. R. 1998. Organizational demography and culture: Insights from a formal model and simulation. Administrative Science Quarterly, 43: 637-667.

Caves, R. E. 1996. Multinational enterprise and economic analysis (2nd ed.). New York: Cambridge University Press.

Child, J. 1972. Organizational structure, environments and performance: The role of strategic choice. Sociology, 6: $1-22$.

Child, J., \& Ellis, T. 1973. Predictors of variation in managerial roles. Human Relations, 26: 227-250.

Collins, J. M. 1990. A market performance comparison of U.S. firms active in domestic, developed and developing countries. Journal of International Business Studies, 2: 271-287.

Cyert, R. M., \& March, J. G. 1963. A behavioral theory of the firm. Englewood Cliffs, NJ: Prentice-Hall.

Daniels, J. D., \& Bracker, J. 1989. Profit performance: Do foreign operations make a difference? Management International Review, 29 (1): 46-56.

Deresky, H. 1997. International management: Managing across borders and cultures. Reading, MA: AddisonWesley.

JOURNAL OF MANAGEMENT, VOL. 26, NO. 6, 2000 
Dichtl, E., Koeglmayr, H., \& Mueller, S. 1990. International orientation as a precondition for export success. Journal of International Business Studies, 21: 23-49.

Directory of corporate affiliations: Who owns whom. 1986-1988. New Providence, NJ: National Register Publishing Co.

Domhoff, G. W. 1983. Who rules America now? Englewood Cliffs, NJ: Prentice-Hall, Inc.

Doz, Y., \& Prahalad, C. K. 1984. Patterns of strategic control within multinational corporations. Journal of International Business Studies, 15: 55-72.

Dun \& Bradstreet (1985) Reference book of corporate managements, New York: Dun \& Bradstreet, Inc., 1985.

Dunning, J. H. 1988. Explaining international production. London: Unwin Hyman.

Eisenhardt, K. M., \& Bourgeois, L. J. III. 1988. Politics of strategic decision making in high-velocity environments: Toward a midrange theory. Academy of Management Journal, 31: 737-770.

Electronic Business. 1986-1988. The electronic business 200.

Fatemi, A. M. 1984. Shareholder benefits from corporate international diversification Journal of Finance, 39 : $1325-1343$.

Finkelstein, S. 1992. Power in top management teams: Dimensions, measurement, and validation. Academy of Management Journal, 35: 505-538.

Finkelstein, S., \& Hambrick, D. C. 1990. Top management team tenure and organizational outcomes: The moderating role of managerial discretion. Administrative Science Quarterly, 35: 484-503.

Finkelstein, S., \& Hambrick, D. C. 1996. Strategic leadership: Top executives and their effects on organizations. Minneapolis/St. Paul: West Publishing Company.

Geletakanycz, M. A., \& Hambrick, D. C. 1997. The external ties of top executives: Implications for strategic choice and performance. Administrative Science Quarterly, 42: 654-681.

Geringer, J. M., Beamish, P. W., \& daCosta, R. C. 1989. Diversification strategy and internationalization: Implications for MNE performance. Strategic Management Journal, 10: 109-119.

Grant, R. M. 1987. Multinationality and performance among British manufacturing companies. Journal of International Business Studies, 18: 79-86.

Haleblian, J., \& Finkelstein, S. 1993. Top management team size, CEO dominance, and firm performance: The moderating roles of environmental turbulence and discretion. Academy of Management Journal, 36 : $844-863$.

Hamel, G., \& Prahalad, C. K. 1989. Strategic intent. Harvard Business Review, 89 (3): 63-76.

Hambrick, D. C., \& Mason, P. A. 1984. Upper echelons: The organization as a reflection of its top managers. Academy of Management Review, 9: 193-206.

Hambrick, D. C., Cho, T. S., \& Chen, M. 1996. The influence of top management team heterogeneity on firms' competitive moves. Administrative Science Quarterly, 41: 659-684.

Hambrick, D. C., \& Schechter, S. 1983. Turnaround strategies for mature industrial product business units. Academy of Management Journal, 26: 231-248.

Harrison, D. A., Price, K. H., \& Bell, M. P. 1998. Beyond relational demography: Time and effects of surfaceand deep-level diversity on work group cohesion. Academy of Management Journal, 41: 96-107.

Hennart, J. F. 1982. A theory of multinational enterprise. Ann Arbor, MI: University of Michigan Press.

Hickson, D. J., Butler, J. R., Cray, D., Mallory, G. R., \& Wilson, D. C. 1986. Top decisions: Strategic decision-making in organizations, San Francisco: Jossey-Bass: 26-42.

Hitt, M. A., Hoskisson, R. E., \& Ireland, R. D. 1994. A mid-range theory of the interactive effects of international and product diversification on innovation and performance. Journal of Management, 20: 297-326.

Hitt, M. A., Hoskisson, R. E., \& Kim, H. 1997. International diversification: Effects on innovation and firm performance in product-diversified firms. Academy of Management Journal, 40: 767-798.

Hitt, M., \& Tyler, B. 1991. Strategic decision models: Integrating different perspectives. Strategic Management Journal, 12: 327-352.

Hughes, J., Lounge, D., \& Sweeney, R. 1975. Corporate international diversification and market assigned measures of risk and diversification. Journal of Financial and Quantitative Analysis, November: 627-637.

Hymer, S. H. 1976. The international operations of national firms: A study of direct foreign investment. Cambridge, MA: MIT Press.

Janis, I. L., \& Mann, L. 1977. Decision making. New York: The Free Press.

Katz, R. 1982. The effects of group longevity on project communication and performance. Administrative Science Quarterly, 27: 81-104.

Keck, S. L. 1997. Top management team structure: Differential effects by environmental context. Organization Science, 8: 143-156.

Kim, W. C., Hwang, P., \& Burgers, W. P. 1989. Global diversification strategy and corporate performance. Strategic Management Journal, 10: 45-57.

Kim, W. C., Hwang, P., \& Burgers, W. P. 1993. Multinationals' diversification and the risk-return trade-off. Strategic Management Journal, 14: 275-286. 
Kindleberger, C. P. 1969. American business abroad: Six lectures on direct investment. New Haven, CT: Yale University Press.

Knickerbocker, F. T. 1973. Oligopolistic reaction and the multinational enterprises. Boston, MA: Harvard University Press.

Kobrin, S. J. 1994. Is there a relationship between a geocentric mind-set and multinational strategy? Journal of International Business Studies, 25: 493-511.

Lant, T. K., Milliken, F. J., \& Batra, B. 1992. The role of managerial learning and interpretation in strategic persistence and reorientation: An empirical exploration. Strategic Management Journal, 13: 585-608.

Lawrence, B. S. 1997. The black box of organizational demography. Organization Science, 8: 1-22.

Lessard, D. R. 1973. International portfolio diversification: A multivariate analysis for a group of Latin American countries. Journal of Finance, 28: 619-633.

Malnight, T. W. 1995. Globalization of an ethnocentric firm: An evolutionary perspective. Strategic Management Journal, 16: 119-141.

McKiernan, P. 1992. Strategies of growth: Maturity, recovery, and internationalization. London: Routhledge.

Markides, C. C., \& Ittner, C. D. 1994. Shareholder benefits from international diversification: Evidence from U.S. international acquisitions. Journal of International Business Studies, 25: 343-366.

Michel, J. G., \& Hambrick, D. C. 1992. Diversification posture and top management team characteristics. Academy of Management Journal, 35: 9-37.

Michel, A., \& Shaked, I. 1986. Multinational corporations versus domestic corporations financial performance and characteristics. Journal of International Business Studies, 16: 89-106.

Mitchell, W., Shaver, M., \& Yeung, B. 1992. Getting there in a global industry: Impacts on performance of changing international presence. Strategic Management Journal, 13: 410-432.

Murray, A. I. 1989. Top management group heterogeneity and firm performance. Strategic Management Journal, 10: 125-141.

Pelled, L. H., Eisenhardt, K. M., \& Xin, K. R. 1999. Exploring the black box: An analysis of work group diversity, conflict and performance. Administrative Science Quarterly, 44: 1-28.

Perlmutter, H. 1969. The tortuous evolution of the multinational corporation. Columbia Journal of World Business, 9-18.

Pettigrew, A. M. 1992. On studying managerial elites. Strategic Management Journal, 13: 163-182.

Pfeffer, J. 1983. Organizational demography, In L.L. Cummings \& B.M. Staw (Eds.) Research in organizational behavior, 5, Greenwich, CT: JAI Press, 299-357.

Prahalad, C. K., \& Bettis, R. A. 1986. Dominant logic: A new linkage between diversity and performance. Strategic Management Journal, 7: 485-501.

Priem, R. L. 1990. Top management team group factors, consensus, and firm performance. Strategic Management Journal, 11: 469-478.

Ramaswamy, R. 1993. Multinationality and performance: An empirical examination of the moderating effect of configuration. Academy of Management Best Paper Proceedings, 142-146.

Rugman, A. M. 1976. Risk reduction by international diversification. Journal of International Business Studies, 7: $75-80$.

Rugman, A. M. 1981. Inside the multinationals: The economics of internal markets. New York: Columbia University Press.

Rugman, A. M., Lecraw, D. J., \& Booth, L. D. 1985. International business: Firms and environment. New York: McGraw-Hill.

Sambharya, R. B. 1996. Foreign experience of top management teams and international diversification strategies of U.S. multinational corporations. Strategic Management Journal, 17: 739-746.

Sanders, W. G., \& Carpenter, M. A. 1998. Internationalization and firm governance: The roles of CEO compensation, top team composition, and board structure. Academy of Management Journal, 41: 158-178.

Smith, K. G., Smith, K. A., Olian, J. D., Sims, H. P., O’Bannon, D. P., \& Scully, J. A. 1994. Top management team demography and process: The role of social integration and communication. Administrative Science Quarterly, 39: 412-438.

Sullivan, D. 1994. Measuring the degree of internationalization of a firm. Journal of International Business Studies, 25: 325-342.

Tabachnik, B. G., \& Fidell, L. S. 1996. Using multivariate statistics. (3rd edition) New York: Harper Collins College Publishers.

Tallman, S., \& Li, J. 1996. Effects of international diversity and product diversity on the performance of multinational firms. Academy of Management Journal, 39: 179-196.

Thomas, A. B. 1988. Does leadership make a difference to organizational performance? Administrative Science Quarterly, 33: 388-400.

Tushman, M. L., \& Romanelli, E. 1985. Organizational evolution: A metamorphosis model of convergence and reorientation, In L. L. Cummings \& B.M. Staw (Eds.) Research in organizational behavior, 7, Greenwich, CT: JAI Press, 171-222.

JOURNAL OF MANAGEMENT, VOL. 26, NO. 6, 2000 
Useem, M. \& Karabel, J. 1986. Pathways to top corporate management. American Sociological Review, 51: $184-200$.

Vernon, R. 1966. International investment and international trade in the product cycle. Quarterly Journal of Economics, 80 (5): 190-207.

Virany, B. Tushman, M., \& Romanelli, E. 1992. An organizational learning model of convergence and reorientation. Organization Science, 3: 72-91.

West, C. T., \& Schwenk, C. R. Top management team strategic consensus, demographic homogeneity and firm performance: A report of resounding nonfindings. Strategic Management Journal, 17: 571-576.

Westphal, J. D., \& Zajac, E. D. 1997. Defections from the inner circle: Social exchange, reciprocity, and the diffusion of board independence in U.S. corporations. Administrative Science Quarterly, 42: 161-183.

Wiersema, M. F., \& Bantel, K. A. 1992. Top management team demography and corporate strategic change. Academy of Management Journal, 35: 91-121.

Wiersema, M. F., \& Bird, A. 1993. Organizational demography in Japanese firms: Group heterogeneity, individual dissimilarity, and top management team turnover. Academy of Management Journal, 36: 996-1025. 